\title{
Metabolic Rate and Body Composition in Rats Nutritionally Deprived before or after Weaning
}

\author{
INGEBORG KRIEGER(')") AND QAMAR TAQI \\ Department of Pediatrics, Wane State University, School of Medicine and the Metabolic Service, Children's \\ Hospital of Michigan, Detroit, Michigan, USA
}

\begin{abstract}
Summary
In order to manipulate cell size and cell number, rats were subjected to nutrient restriction either prenatally and until weaning at 3 weeks (group I), or from 3 until 10 weeks (group II). Body weights of group I rats were $30 \%$ of normal at the height of deprivation at 3 weeks. By 16 weeks of age maximum weights were reached, which remained subnormal in the majority; by 26 weeks only one of six rats had attained a normal weight. Body weights of group II were $27 \%$ of normal at the height of deprivation at $\mathbf{1 0}$ weeks; subsequently, only one of six did not recover. The weight, protein, and DNA content of liver, kidney, and heart were significantly decreased. The combined weight and protein content of the three organs was $30 \%$ of normal in group I and $25 \%$ of normal in group $I I$; the $D N A$ content of the three organs was $57 \%$ and $38 \%$ of normal in group $I$ and group $I I$, respectively. The greater deficit in weight than DNA content, and the mean protein/DNA ratios reflect a decrease in cell size (or increase in the cell density) of the three organs, which was greater in group I $(60 \%)$ than group II $(71 \%)$. Muscle cell density was increased in group $I$, but not in group $I I$. At 16 weeks of age all parameters were similar in the two experimental groups (ranging from $68 \%$ to $82 \%$ or normal). Organ weight, protein, and DNA content remained deficient only in group I; these values were $74 \%, 70 \%$, and $77 \%$ of normal, respectively, at 32 weeks. The deficit was proportionate to the deficit in body weight.

The basal metabolic rate was measured $17-20 \mathrm{hr}$ after food removal (BMIR) on the day the animals were killed. In group I and $I I$ correlations between the BNIR and four parameters of body composition were linear during a 4-period at the height of deprivation. Comparison of means from the regressions showed no difference between group $I$ and $I I$, or between these groups and normal controls with regard to the BNIR per body weight, organ weight, and organ protein. The BMR per mg DNA was lower in group $I$ and $I I$ than in normal control rats $(P<0.05)$. The BNIR of normal rats age 3-32 weeks showed a curvilinear correlation with body weight $(\mathrm{BWt}), \mathrm{BNIR}=1.24 \mathrm{BWt}^{0.5 \times 3}$; organ weight $(\mathrm{OWt}), \mathrm{BMR}=4.30 \mathrm{OWt^{0.7tit }}$; and organ protein $(\mathrm{OPr}), \mathrm{BMIR}=4.30 \mathrm{OPr}{ }^{n . t i n 4}$. By contrast, the regression on DNA was linear $(B M R=7.97+0.449)$, although marked changes in body composition occurred between 3 and 32 weeks.
\end{abstract}

\section{Speculation}

Future analyses of body composition of infants with small-forgestational age dwarfism may identify a type which is characterized by a decrease in cell number per unit of weight and height. This study indicates that such a decrease in total body cell density can be diagnosed by measuring the BNR, which thus may prove to be a practical tool in the identification of infants with a poor growth potential because of prenatal influences and genetic factors.
Nutrient restriction which operates in rats prenatally and before weaning has a profound and frequently lasting effect on growth (14), which appears to be because insults which operate during the hyperplastic phase of growth affect cell multiplication more than insults which occur later on. Cell size is affected to a greater extent in growth failure which is caused by nutrient restriction in the postweaning period. Upon refeeding cell size increases, but recovery through cell multiplication appears to be limited. As a result, body composition varies depending on the timing of the insult and degree of recovery.

Our own studies in human infants indicate that the BMR is also a function of the time at which an insult to growth occurs. We reported that infants with growth failure due to postnatal malnutrition have significantly higher BMR's than infants of the same weight or height who at birth were small for length of gestation, remained small, and in the hospital resisted efforts to induce weight gain (9). The highest values were seen in infants with postnatal malnutrition who subsequently gained weight in the hospital and ultimately demonstrated catch-up growth for height as well.

The low BMR of infants with small-for-gestational-age dwarfism appeared to be caused by an abnormal body composition, as thyroid function was normal (7). Moreover, since there is experimental evidence that cell number is the major determinant of the BMR (4), we concluded that low values were probably due to a decrease in the cell number of the total body or major organs rather than a decrease in cell size which increases cell density and, according to our hypothesis, should raise the BMR per body' weight.

In the current study we attempted to test the hypothesis that the low BMR's of infants with growth failure of prenatal onset reflect a low cell number. We proceeded by manipulating cell number and cell size through nutrient restriction of male and female rats, either from mating until weaning or thereafter unti] 10 weeks of age. We tested them during deprivation when body composition was abnormal. We also tested a group of normil rats over a prolonged period of time when we could expect body composition to change. We reasoned that-irrespective of such a change-correlations should be linear between the BMR and those parameters of body composition that are reflected by the BMR, either protein content and weight which are indices of cell mass, or DNA content which is an index of cell number (1). Moreover, we hoped to find a stage during which there was a difference in body composition between rats deprived before or after weaning, which might be reflected by the BMR.

\section{METHODOLOGY}

\section{PREPARATION OF ANIMALS}

Sprague-Dawley rats (Spartan Research Animals, Inc.) were used throughout the experiment. Mature, female rits who weighed between 180 and $200 \mathrm{~g}$ and had not been bred before 
were given a "low $(8 \%)$ protein diet" (comprised of $8 \%$ casein, $78 \%$ starch, $10 \%$ vegetable oil, $4 \%$ salt mixture USP XIV, and complete vitamin supplement (Nutritional Biochemicals)) from 2 or 3 weeks before mating until weaning (5) at 3 weeks, except for rats with poor milk supply (evidenced by gastric filling of the suckling rat), who were given normal rat chow during the first 3 postpartum days. The offspring of these rats who had a low weight at 3 weeks of age were placed in group 1 . Group II rats were offspring of normal rats who were deprived only from weaning at 3 weeks of age until 10 weeks by feeding the same low $8 \%$ protein diet. A "normal protein test diet" $(27 \%)(27 \%$ vitamin free casein, $59 \%$ starch, $10 \%$ vegetable oil, $4 \%$ salt mixture USP XIV, and vitamin diet fortification mixture (Nutritional Biochemicals)) was given to both groups after the period of deprivation, i.e., to group I from 3-16 weeks, and to group II from 10-16 weeks. Normal control rats and the mothers of control and group II rats received a commercial laboratory ration $(23 \%$ protein, $4.5 \%$ fat, no more than $6.0 \%$ fiber, $8.0 \%$ ash, $2.5 \%$ mineral and vitamin supplement (Purina)). Because of price considerations, all rats who were followed for more than 16 weeks received also the commercial laboratory ration with the $23 \%$ protein content. Animal preparation was the same for the first and second study.

\section{EXPERIMIENTAL DESIGN}

Sixteen or 17 rats were used to make up groups $I, I I$, and the control group; in each group four or five rats were killed at 3 weeks and four at 10,16, and between 24 and 32 weeks. The data from this study are used mainly to determine means and ranges for organ weights, protein, and DNA content at the four time points. Concurrently, metabolic rates were measured 5-7 hr after food removal, together with body weights, in: $(l)$ normal rats (40 measurements) to provide a scattergram on age, and (2) six to eight rats of groups $I$ and $I I$ to provide longitudinal data (Figs. 1 and 2) and recovery values for the metabolic rate.

In a second group of rats BMR measurments were made $17-$ 20) hr after food removal. Eight animals were studied at the height of deprivation: In group I five were killed at 3 weeks, and one each at 4, 5 , and 6 weeks; in group $/ /$ one rat each was killed at $6,7,8$, and 9 and four at 10 weeks. Twenty control rats were observed from 3-32 weeks: four were killed at 3 weeks. four at weekly intervals up to 7 weeks, and 12 more between 10 and 32 wecks.

\section{METABOLIC RATE MEASUREMENTS}

The metabolic rates were measured at a constant interval after food removal from the cages. Because of marked variability of the metabolic rate in the waking state, presumably because of different levels of activity, panting, etc., rats were kept in silence and semidarkness and measurements were begun when they were calm and motionless, with eyes closed. At least four readings could be obtained while the animals remained calm. The lowest reading which could be repeated two times or more was accepted. Adherence to these conditions made it possible to reproduce measurements within $\pm 5 \%$ of the original value.

Oxygen consumption and respiratory quotient were used to calculate the metabolic rate. Measurements were made with a "flow-through" gas analyzer (Kipp-Zonen) that utilizes an open system in which the animals breathed, under a translucent plastic hood, room air that was suctioned through at a rate of 0.8 liter/ min. The instrument analyzes differences in the oxygen and carbon dioxide concentration of inspired and expired air by measuring differences in heat conductivity.

\section{BIOCHEMIICAL ANALYSIS}

Rats were killed with an overdose of ether and died because of bleeding from the incision of major abdominal vessels within 4 min of ether administration. Brain, liver, kidneys, heart, and biceps muscle were excised, blotted free of blood, and weighed on an analytic balance. One-half of each organ was saved and the other homogenized in ice-cold deionized water by use of a high speed mechanical cell homogenizer. A solution equivalent to approximately $250 \mathrm{mg}$ wet tissue was extracted following the recommendations of Munro and Fleck for use of the SchmidtTannhauser method (10), and DNA was estimated by Burton's modification of the diphenylamine method (2). Protein was determined with trinitrobenzene sulfuric acid according to the method of Goodwin and Choi (3).

\section{RESULTS}

\section{LONGITUDINAL MEASUREMENTS OF BODY IVEIGHT ANI MIETABOLIC RATE}

Body weights of six group $I$ and seven group // rats who were followed longitudinally (Figs. 1 and 2) seem to be representative of the animals who were killed for study of organ composition (Table 1). In group I body weights were approximately $30 \%_{c}^{\circ}$ of normal at weaning; by 16 weeks maximum weights were reached but there was little further growth, and only one of the six rats followed longitudinally attained a normal weight. By contrast, catch-up growth contimued in group $I /$ after 16 weeks, and only one of six rats did not reach a normal weight, although the mean weight of this group at the height of deprivation at lo weeks was as low as in group $I, 27 \%$ of normal. Recovery was complete around 24 weeks of age. Two of four group II rats who were followed up to 32 weeks had unusually high body weights by that time.

Longitudinal measurements of the metabolic rate, measured 5-7 hr after food removal, showed changes which paralleled those of body weight. This was impressive in group /I becaluse of the severe growth arrest that occured between 3 and 10 weeks of age. There was a tendency for the metabolic rate measurements to be higher during periods of rapid growth. evidenced by a slight decline, which occurred after 8 wecks in group) $I$ rats and after 14 weeks in normal rats (Figs. 1 and 2).

\section{ORGAN WEIGIT, PROTIIN, ANID DNA CONIENT}

Brain. Mean brain weight of group I was decreased to 79\% of the normal mean at 3 weeks. However, this decrease, as well as the smaller decrease of brain DNA and protein content, was not significant because of the small sample size. Group $I I$ had normal values for brain weight, protein, and DNA.

Liver, Kidney and Heart (Table I). (The terms organ weight, organ protein, and organ DNA will be used to express the sum of the values for these three organs; the inclusion of brain in this sum will be indicated.)

At the height of deprivation organ weight, protein, and IDNA content were significantly decreased in both groups. The degree of this decrease was similar in the three organs. Organ weight and protein content were approximately 30 \% of normal in group $I$ and $25 \%$ of normal in group $I I$. The decrease in organ weight was in both groups comparable to the decrease in body weight. Organ DNA content was $57 \%$ of normal in group $I$ and $38 \%$ of normal in group II. The comparatively greater decrease in organ weight and protein content reflects a decrease in cell size, that is, increase in cell density, which was greatest in group $I$.

Protein/DNA Ratio (Table 2). Indeed, comparison of the protein/DNA ratios of the two experimental groups with those of the control group did suggest a decrease in cell size at the height of deprivation; in group I mean protein/DNA ratio was $60 \%$ of normal, and in group $/ 171 \%$ of normal.

\section{CATCH-UP GROWTH (TABIL 2)}

The insult which occurred in group I during a period of rapid cell multiplication had to be made up after age 3 weeks, $i$.e., during a period when cell multiplication was still very active. 

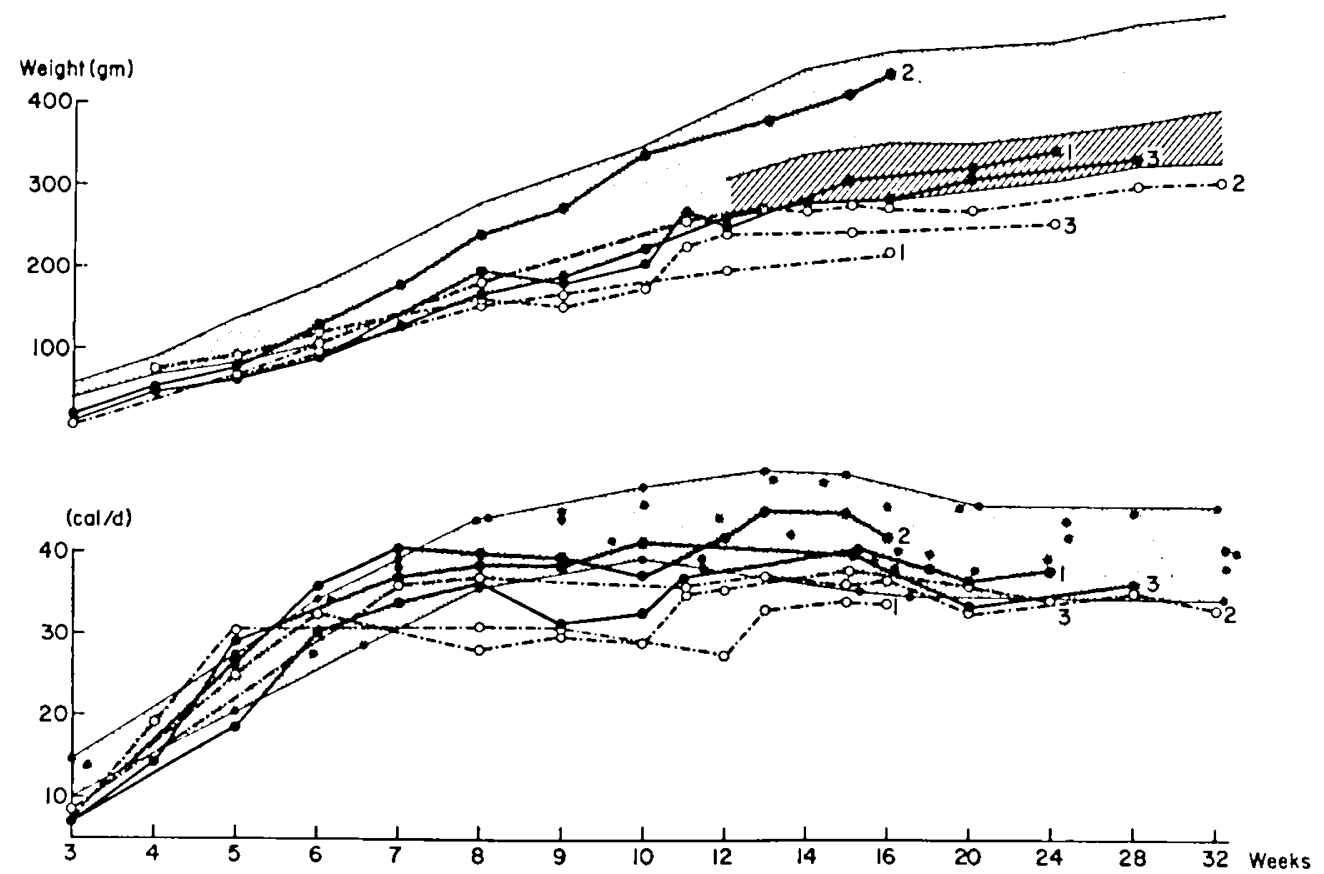

Fig. 1. Longitudinal measurements conducted in group $I$ on three male $(--)$ and three female (-·--) rats. Top: body weight; bottom: corresponding metabolic rate, measured 5-7 hr after food removal, expressed in calories per day. Shaded are'a encloses 4 () normal values obtained at intervals between 3 and 32 weeks of age; the diagonally shaded area for body weight represents the difference between the lower limit of normal for males (upper margin) and females (lower margin).

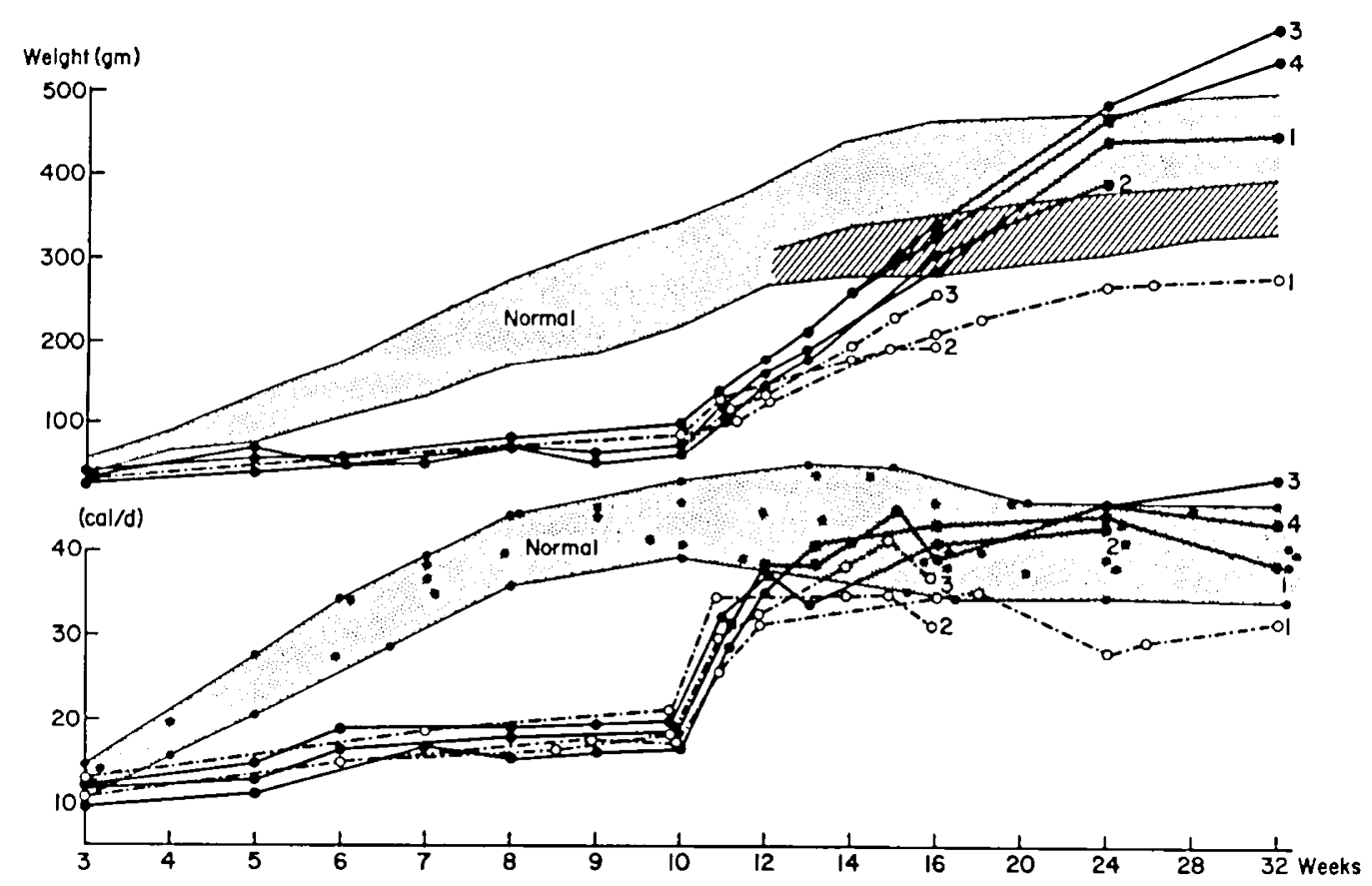

Fig. 2. Longitudinal measurements conducted in four male and three female group $/ /$ rats. (Symbols as for figure 1.)

This is evidenced in normal rats by the 6 -fold increase in organ weight which occurred between 3 and 10 weeks of age and which was not attributable to an increase in cell size because the protein/DNA ratio showed only a 1.4 -fold increase. Consequently, the major share of the catch-up growth of group $I$ had to be accomplished through cell multiplication, i.e., a 7.7 -fold increase in organ DNA. This is also reflected by the 13 -fold increase in organ weight which was accompanied by only a 1.9 . fold increase of the protein/DNA ratio.

Catch-up growth occurred in group $I I$ at a time when in normal rats cell multiplication had ceased. Organ weights showed only a 3.3 -fold increase during recovery between 10 and 16 weeks of age, whereas the corresponding protein/DNA ratio increased 2-fold. Two-thirds of the weight increase was thus accounted for by an increase in "cell size." However, approximately two-thirds of this increase can also be accounted for by cell multiplication since organ DNA doubled during this time.

At 16 weeks all parameters were similar in the two experimental groups. After this time group II showed a further increase in body weight, organ weight, and organ DNA content and caught up or even surpassed the normal controls. In contrast, group I demonstrated no significant increase for these three parameters and thus showed a deficit at 24 and 32 weeks. However, this deficit was not significant because of the small sample size.

Organ protein of all three groups was highest at 16 wecks, but declined thereafter, although organ weights remained stable in 
group $I$ and controls and increased in group $I I$. The same phenomenon is expressed by the protein/DNA ratios, which were higher at 16 than at 24 weeks (Table 2).

The abnormalities of group $I$ in organ weight, protein, and DNA content which persisted up to 32 weeks of age were proportionate to the decrease in body weight.

BMR RELATED TO BODY WEIGHT AND WEIGHT, PROTEIN, AND DNA CONTENT OF PARENCHYMAL ORGANS, INCLUDING BRAIN

For the correlation analyses metabolic rates were measured in a truly basal state, 17-20 hr after food removal (BMR). In normal rats, age 3-32 weeks, correlations between BMR and body weight, organ weight, and organ protein content were best expressed by a curvilinear regression line (Figs. 3-5). By contrast, the correlation between BMR and organ DNA content was linear (Fig. 6).

In group $I$ and $I I$ correlations between the BMR and the four parameters of body composition were linear during a 4-week period at the height of deprivation. Comparison of means from the regression (Student $t$-test) showed that there was no difference between groups $I$ and $I I$, or between these groups and normal controls with regard to the BMR per body weight, organ weight, or organ protein content. In contrast, groups $I$ and $I I$ had

Table 1. Effect of mutrient restriction on growth ${ }^{1}$ of rats deprived before (group I) or after weaning (group II)

\begin{tabular}{|c|c|c|c|c|c|c|c|c|}
\hline & 3 weeks & $(\%)^{2}$ & 10 weeks & $(\%)^{2}$ & 16 weeks & $(\%)^{2}$ & 24-32 weeks & $(\%)^{2}$ \\
\hline \multicolumn{9}{|l|}{ Body weight (g) } \\
\hline Group I & $15^{3}$ & $(30 \%)$ & $212^{4}$ & \multirow{3}{*}{$(27 \%)$} & 300 & $(82 \%)$ & $303^{4}$ & \multirow[t]{3}{*}{$(76 \%)$} \\
\hline Group II & & & $78^{3}$ & & 270 & $(73 \%)$ & 418 & \\
\hline Normal control & 46 & & 289 & & 368 & & 399 & \\
\hline \multicolumn{9}{|l|}{ Organ weight ${ }^{3}(\mathrm{~g})$} \\
\hline Group I & $0.84^{3}$ & $(30 \%)$ & 10.88 & \multirow{3}{*}{$(25 \%)$} & 12.81 & $(81 \%)$ & 12.56 & \multirow[t]{3}{*}{$(74 \%)$} \\
\hline Group II & & & $3.70^{3}$ & & 12.13 & $(77 \%)$ & 16.63 & \\
\hline Normal control & 2.43 & & 14.70 & & 15.75 & & 16.95 & \\
\hline \multicolumn{9}{|l|}{ Organ protein $(\mathrm{mg})$} \\
\hline Group I & $151^{4}$ & $(30 \%)$ & $2,055^{3}$ & \multirow{3}{*}{$(25 \%)$} & 3849 & $(68 \%)$ & $2,552^{4}$ & \multirow[t]{3}{*}{$(70 \%)$} \\
\hline Group II & & & $1,087^{3}$ & & 4079 & $(72 \%)$ & 3,492 & \\
\hline Normal control & 458 & & 4,469 & & 5699 & & 3,653 & \\
\hline \multicolumn{9}{|l|}{ Organ DNA $(\mathrm{mg})$} \\
\hline Group I & $4.44^{4}$ & $(57 \%)$ & $34.05^{4}$ & \multirow{3}{*}{$(38 \%)$} & 41.38 & $(72 \%)$ & 45.05 & \multirow[t]{3}{*}{$(77 \%)$} \\
\hline Group II & & & $20.74^{3}$ & & 39.59 & $(69 \%)$ & 54.83 & \\
\hline Normal control & 7.75 & & 56.17 & & 57.61 & & 58.31 & \\
\hline
\end{tabular}

'Values are means of two male and two female rats in each group and age category.

${ }^{2}$ Percentage of normal.

${ }^{3}$ Comparison with normal controls (based on Student $t$-test), significant at $1 \%$ level.

4 Comparison with normal controls (based on Student $t$-test), significant at the $5 \%$ level.

s Sum of three organs: liver, kidney, and heart.

Table 2. Comparison of changes in cell size and organ weight during nutrient restriction and through recovery ${ }^{1}$ of rats deprived before 3 weeks (group I) or between 3 and 10 weeks (group II)

\begin{tabular}{|c|c|c|c|c|}
\hline Group & 3 weeks (range) & 10 weeks (range) & 16 weeks (range) & $\begin{array}{c}24-32 \text { weeks } \\
\text { (range) }\end{array}$ \\
\hline \multicolumn{5}{|c|}{ Organ $^{2}$ protein/DNA ratio } \\
\hline \multicolumn{5}{|c|}{ Group I } \\
\hline Liver & $33(26-39)$ & $66(38-105)$ & $72(40-100)$ & $52(45-58)$ \\
\hline Kidney & $33(17-50)$ & $68(47-88)$ & $113(89-129)$ & $68(64-79)$ \\
\hline Heart & $43(22-73)$ & $68(45-92)$ & $137(127-164)$ & $95(79-107)$ \\
\hline Mean & $36(\times 1.9 \rightarrow)^{3}$ & 67 & 107 (minus $35 \rightarrow)^{3}$ & 72 \\
\hline \multicolumn{5}{|l|}{ Group II } \\
\hline Liver & $56^{4}(33-80)$ & $51(31-86)$ & $98(73-146)$ & $62(53-103)$ \\
\hline Kidney & $63^{4}(51-85)$ & $61(36-82)$ & $122(93-167)$ & $65(61-71)$ \\
\hline Heart & $62^{4}(50-87)$ & $69(63-75)$ & $132(109-163)$ & $92(79-116)$ \\
\hline Mean & 60 & $60(\times 2.0 \rightarrow)^{3}$ & $119{\text { (minus } 46 \rightarrow)^{3}}^{3}$ & 73 \\
\hline \multicolumn{5}{|l|}{ Normal control } \\
\hline Liver & $56(33-80)$ & $79(64-99)$ & $114(54-195)$ & $58(48-67)$ \\
\hline Kidney & $63(51-85)$ & $87(68-134)$ & $114(85-160)$ & $79(63-98)$ \\
\hline Heart & $62(50-87)$ & $85(72-108)$ & $139(116-167)$ & $100(92-170)$ \\
\hline Mean & $60(\times 1.4 \rightarrow)^{3}$ & $84(\times 1.5 \rightarrow)^{3}$ & $122(-43 \rightarrow)^{3}$ & 79 \\
\hline \multicolumn{5}{|l|}{ Organ $^{2} w t, g$} \\
\hline Group I & $0.84(\times 13.0 \rightarrow)^{3}$ & 10.88 & 12.81 & 12.56 \\
\hline Group II & $2.43^{4}$ & $3.70(\times 3.3 \rightarrow)^{3}$ & 12.13 & 16.63 \\
\hline Normal control & $2.43(\times 6.0 \rightarrow)^{3}$ & 14.70 & 15.75 & 16.95 \\
\hline \multicolumn{5}{|c|}{ Muscle protein/DNA ratio } \\
\hline Group I & $31(20-39)$ & $140(90-345)$ & $351(263-440)$ & $277(178-420)$ \\
\hline Group II & $65^{4}(33-81)$ & $138(120-151)$ & $352(300-400)$ & $231(195-245)$ \\
\hline Normal control & $65(33-81)$ & $154(134-171)$ & $319(240-380)$ & $292(229-371)$ \\
\hline
\end{tabular}

1 Two male and two female rats were tested at each time point.

2 Includes liver, kidney, and heart.

${ }^{3}$ Indicates change of mean value from preceding to following time point.

4 The value for normal rats is used. 


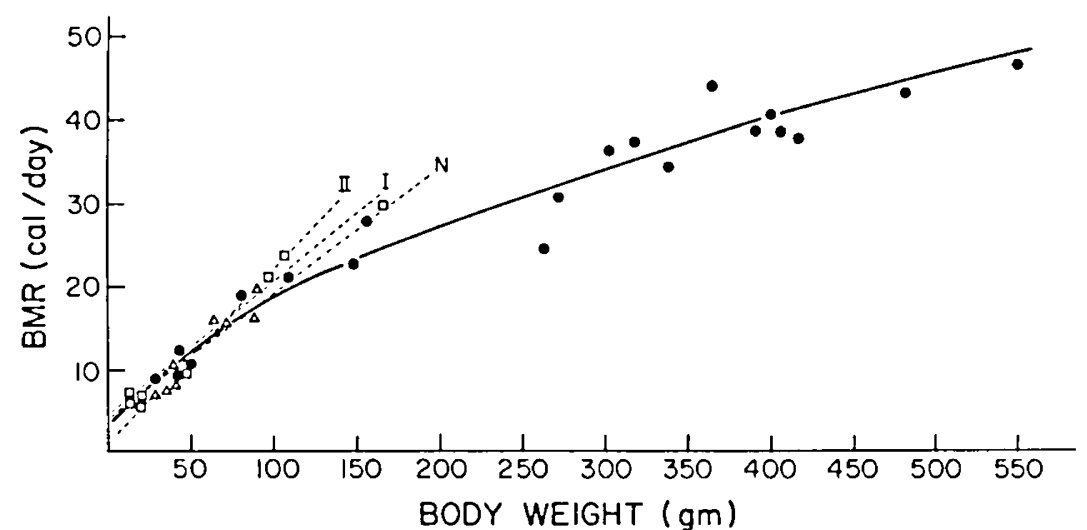

Fig. 3. Correlations (- - ) between the basal metabolic rate (B.IIR) (calories per day) and body weight (BW't) in 3-7-week-old rats of group $I$ ( $\square$ ). 6-10-weck-old rats of group $I I(\triangle)$, and normal control rats $(N, \bullet)$, eight in each group. The uninterrupted curvilinear regression line is for 20 normal rats, age $3-32$ weeks. BMR $=1.24 \mathrm{BWV}^{0.56 \cdot 3} ; r=0.981$. (For regressions and statistical comparison, see Table 3.)

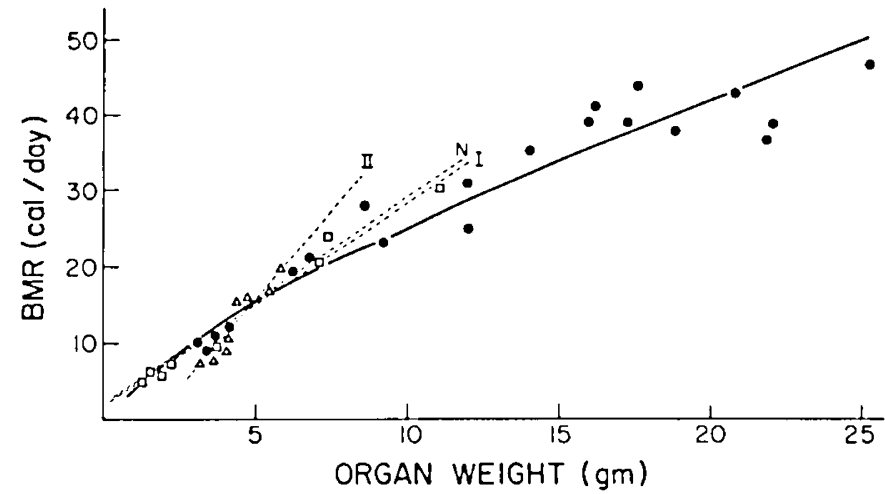

Fig. 4. Correlations (- - ) between the basal metabolic rate (B,MR) (calories per day) and organ weight (OWt) in 3-7-week-old rats of group $I(\square), 6-10$-weck-old rats of group $I /(\triangle)$, and normal control rats $(N, \bullet)$; eight in each group. The uninterrupted curvilinear regression line is for 20 normal rats, age 3-32 weeks. B.MR $=4.30 \mathrm{OW}^{\mathrm{th}}$ iter; $r=0.976$. (For regressions and statistical comparison, sec Table 3.)

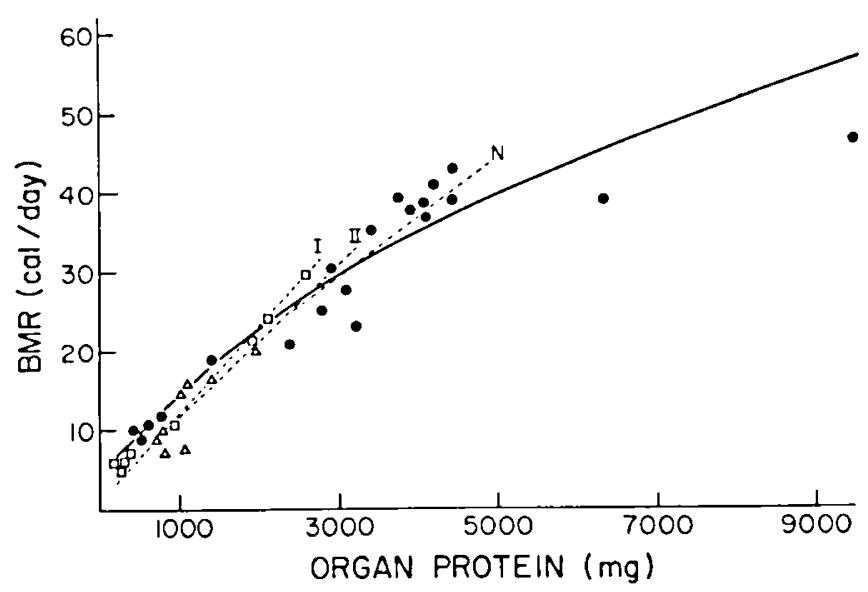

Fig. 5. Correlations (- - ) between the basal metabolic rate (BMR) (calories per day) and organ protein (OPr) in 3-7-weck-old rats of group $I(\square), 6-10$-weck-old rats of group $I I(\triangle)$, and normal control rats $(N, \bullet)$; eight in each group. The uninterrupted curvilinear regression line is for 20 normal rats, age 3-32 weeks. BMR = 4.30 $\mathrm{OPr}^{11 \text { fint }} ; r=0.968$. (For regressions and statistical comparison, sec Table 3.)

a lower BMIR per mg organ DNA than normal rats $(P<0.05)$.

Upon recovery, between 16 and 32 weeks of age, eight animals in each group had measurements of the metabolic rate 5-7 hr after food removal, and these values indicated no significant

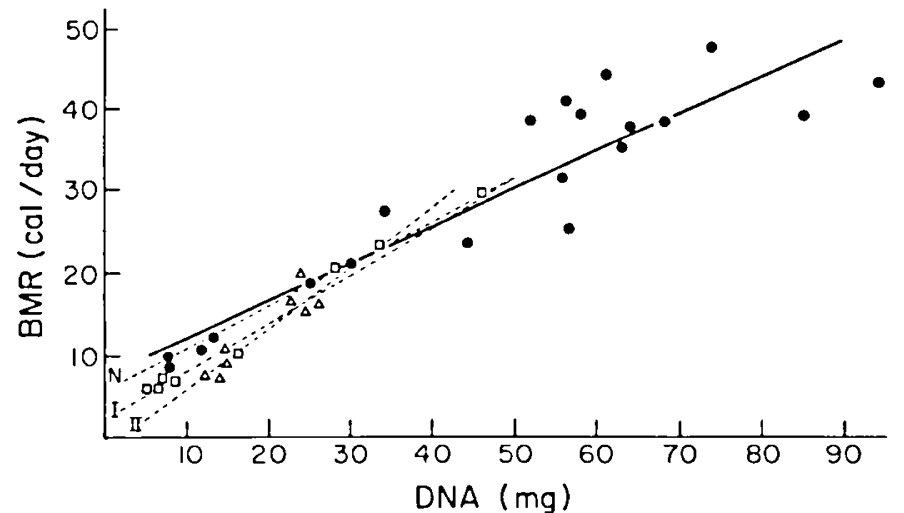

Fig. 6. Correlations (- - ) between the balsal metabolic rate (B.MR) (calories per day) and organ DNA in 3-7-weck-old rats of group I (口), (1-10-week-old rats of group $I I(\triangle)$, and normal control rats $(N, \bullet)$; eight in each group. The uninterrupted linear regression line is for 20 normal rats, age 3-32 weeks. BMR $=7.97+0.449$ DNA; $r=$ 0.915. (For regressions and statistical comparison, see Table 3.)

difference between the experimental groups and normal controls.

\section{DISCUSSION}

We have analyzed in this study of rats with two types of growth failure the relationship between the metabolic rate and body composition, mainly the cell number and cell size of four major organs, brain, liver, kidney, and heart. We expected to find a period, either at the height of deprivation or during recovery. when the BMR per body weight would be analogous to the low values observed by us in infants with small-for-gestational age dwarfism (9). Analysis of changes in body composition during such a period, hopefully, would allow determination of factors responsible for these low BMAR values. We caused, through nutrient restriction prior to weaning at 3 weeks, severe and irreversible growth failure, which was similar in type to the growth failure observed by others $(5,6,11)$, and we followed the animals until 32 weeks of age. Although the absolute BMR (calories per day) was low at the height of deprivation. we failed to detect a period when the BMIR per body weight was low. because the BMR paralleled changes in body weight.

We had speculated that the BMR is a measure of cell number. that low values per body weight reflect a decrease in cell density of individual organs or the total body. and that this decrease is the result of growth recovery through cell enlargement. However, at no time during growth recovery was a decrease in cell density observed. At the height of deprivation we found, as have 
Table 3. Correlations between basal metabolic rate $(B M R)^{1}(y)$ and parameters of body composition ( $x$ ) in growth-retarded rats at height of deprivation

\begin{tabular}{|c|c|c|c|}
\hline $\mathrm{x}$ & Group $I,{ }^{2}$ y & Group $I I, 2$ y & Normal, ${ }^{2}$ \\
\hline Body weight $(\mathrm{BWt}), \mathrm{g}$ & $\begin{array}{l}3.57+0.170 \mathrm{BWW} \\
(r=0.992)\end{array}$ & $\begin{array}{l}0.19+0.213 \mathrm{BWt} \\
(r=0.953)\end{array}$ & $\begin{array}{l}4.72+0.144 B W \mathrm{Wt} \\
(r=0.971)\end{array}$ \\
\hline Organ weight $(O W t),{ }^{3} g$ & $\begin{array}{l}1.33+2.7420 \mathrm{Wt} \\
(r=0.989)\end{array}$ & $\begin{array}{l}-8.09+4.7860 \mathrm{OWt} \\
(r=0.931)\end{array}$ & $\begin{array}{l}0.74+2.8490 \mathrm{Wt} \\
(r=0.966)\end{array}$ \\
\hline Organ protein (Pr), mg & $\begin{array}{l}1.75+0.011 \mathrm{Pr} \\
(r=0.979)\end{array}$ & $\begin{array}{l}1.58+0.010 \mathrm{Pr} \\
(r=0.780)\end{array}$ & $\begin{array}{l}7.70+0.006 \mathrm{Pr} \\
(r=0.957)\end{array}$ \\
\hline Organ DNA, mg & $\begin{array}{l}1.88+0.634 \mathrm{DNA} \\
(r=0.993)\end{array}$ & $\begin{array}{l}-2.17+0.777 \mathrm{DNA} \\
(r=0.9() 4)\end{array}$ & $\begin{array}{l}6.01+0.487 \mathrm{DNA} \\
(r=0.926)\end{array}$ \\
\hline
\end{tabular}

1 The BMR was measured 17-20 hr after food removal, and is expressed in calories per day.

2 Comparison of means from the regression lines: group I versus group $I I$ was not significantly different for any independant variable. Groups $I$ and $I I$ versus normal controls were each significantly different $(P<0.05)$ only for DNA.

" liver, kidney, heart, and brain.

other investigators before, an increase in the cell density of major organs in both groups, which should have raised the BMR per organ weight and organ protein, providing cell number is indeed a major determinant of the BMR. An elevation per gram of organ weight or organ protein was not observed.

Analogous to some other reports (15), the deficit in organ weight which developed during deprivation in both groups was similar to the deficit in body weight. This weight deficit, coupled with an increase in cell density of major organs and muscle, should raise total body cell density and consequently the BMR per body' weight, measured at the height of deprivation. Again. this was not observed.

The BMR per mg organ DNA was significantly lower in groups $I$ and $I I$ than in normal rats. This is indicative of a decrease in the metabolic activity of individual cells. The decrease was independent of the type of growth failure, because it was observed in group $I$ rats with a poor prognosis for complete growth recovery as well as in group II rats with reversible growth failure. It appears that this decrease in cellular metabolic activity offset the effect of increased cell density and thus explains our failure to demonstrate at the height of deprivation an increased metabolic activity per body weight, organ weight, or organ protein.

The low cellular metabolic rate may have been due to a decrease in thyroid function. This is a likely cause since it was observed in both groups at the height of deprivation, as group I was pulling out of it after weaning, and as group $I I$ was approaching the end of nutrient restriction at 10 weeks. Low absolute metabolic rates (calories per day) and decreased total and free serum thyroxin levels were seen by us in human infants with redundant skin folds suggestive of weight loss; their abnormality did not change immediately upon refeeding (7). The low BMR observed by us in human infants with small-for-gestational age dwarfish (9) was probably not due to a decrease of the cellular metabolic rate because these infants had normal thyroid function and there was no change after weight gain induced by forced feeding (7). The intrauterine insult which caused irreversible growth failure in these infants was evidently different from the nutrient restriction that caused permanent stunting in rats of the current study. The association of congenital anomalies with growth failure in a high pereentage of our cases supports this explanation.

Human infants who suffer chronic malnutrition after birth have an increased BMR per body weight (9) and are thus not like the rats of group $1 /$. This increase is generally attributed to the preponderance of tissues with a high resting metabolic rate, mainly brain and major organs like the liver. This preponderance develops because tissues like fat and muscle with a relatively low resting metabolic rate are primarily affected by malnutrition. It is not surprising that the BMR per body weight differs in rats because the ratio between tissues of different metabolic activity is not the same as in humans. Moreover, our own studies suggest that failure to thrive due to chronic malnutrition differs from malnutrition that is associated with acute weight loss, because the absolute metabolic rate (calories per day) is not depressed and does not change with weight gain until linear growth occurs (7).

The BMR data of normal rats are comparable to those reported by Watts and Gurley (12). In conjunction with the organ data, they provided us with an opportunity to study the importance of cell number as a determinant of the BMR by yet another approach. By following the BMR of normal rats from birth to 32 weeks of age we observed that absolute values failed to increase further after 10 weeks, although body weight as well as organ and muscle protein content continued to increase. Failure of the BMR to rise further was associated with cessation of cell multiplication. This lack of change of the cellular metabolic rate is best demonstrated by the linear regression of the BMR on DNA. The regressions of the BMR on body weight, organ weight, and organ protein content were therefore curvilinear. These observations support the hypothesis that cell number is a major determinant of the BMR. A similar conclusion was reached by Gray and Deluca (4), who studied the oxygen uptake of tissue taken from the diaphragm of rats with abnormal body composition. Consequently, metabolic activity is more suitably expressed on a per cell basis than on the more usual basis of weight or size. This should be taken into account when interpreting metabolic data.

The data showed also that protein/DNA ratios, which are customarily used to reflect cell size, have to be interpeted with caution. A continuing increase in organ protein content which occurred in normal rats after 10 weeks of age was not associated with an increase in organ weight, and the decrease in organ protein content which occurred in all groups after 16 weeks of age was not accompanied by a loss of weight.

The findings of this study do not exclude our hypothesis that the low BMR of human infants with small-for-gestational age dwarfism (2) is due to a decrease in cell number. However, the insult which we chose was apparently not suitable. It did not induce the appropriate change in body composition, which was anticipated during the recovery phase (16). Ligation of vessels of the uterine horn may provide a better animal model (13) because the weight deficit of major organs, like the liver, is in these rats greater than the deficit in body weight. This should lead to a decrease in total body cell density, providing that a decrease in organ weight is not balanced by an increase in cell density or normal brain size, a characteristic feature of this type of growth retardation. Teratogenic insults capable of inducing permanent linear growth failure may be best in duplicating the growth failure of infants with small-for-gestational age dwarfism.

\section{CONCLUSION}

Nutrient restriction of rats from $(l)$ conception until weaning (2) after weaning until 10 weeks of age caused severe deficits in body weight, parenchymal organ weight, organ 
protein, and DNA content with an increase in cell density. By 24 weeks, only rats subjected to early restriction showed persistent deficit which was similar for all four parameters, indicating normal cell density. Protein/DNA ratios decreased after 16 weets in experimental and control rats. At the height of deprivattion both groups had a normal BMR per body weight, organ weight, and protein content, but the BNR per mg organ DNA was low. This reflects a low cellular metabolic rate which evidently offset the effect of increased cell density on the BMR per body weight and organ weight and protein content. The BMR of normal rats showed a positive linear correlation with DNA, despite marked changes in body composition which occurred between 3 and 32 weeks of age. By contrast, the correlations between BMR and body weight, organ weight, and organ protein content were curvilinear. Absolute BMR values (calories per day) failed to increase after 10 weeks of age despite continued weight gain because cell multiplication ceased at that time.

\section{REFERENCES AND NOTES}

1. Boivin, A., Vendrely, R., and Vendrely, C.: L'Acide desoxyribonucleique du noyan cellulaire, dépositaire des caracteres héreditaires; arguments dordre analytique. C. R. Acad. Sci., 226: 1061 (1948).

2. Burton, $K^{\prime}$ : A study of the conditions and mechanism of the diphenylamine reaction for the colorimetric estimation of deoxyribonucleic acid. Biochem. J. 62: $315(1956)$.

3. Goodwin, J. F., and Choi, S. Y.: Quantification of protein solutions with trinitrobenzenesulfonic acid. Clin. Chem.. 16: 24 (1971)).

4. Gray, D. E., and Deluca, H. A.: Use of desoxyribonucleic acid as a reference standard in metabolic experiments. Amer. J. Physiol., 184: 301 (1956).

5. Hsuch, A. M.: Protein/calories in the maternal diet on the development of the offspring [Abstr.]. Fed. Proc., 29: 364 (1970).
6. Hsuch, A. M., Agustin, C. F., and Chow, B. F.: Growth of young rats after differential manipulation of maternal diet. J. Nutr., 91: 195 (1967).

7. Kricger, 1., and Taqi, Q.: Free serum thyroxine level and metabolic rate. Amer. J. Dis. Child., 129: 380 (1975)

8. Krieger, I., and Whitten, C. F.: Energy metabolism in infants with growith failure due to maternal deprivation, undernutrition, or causes unknown. J. Pediat., 75: 374 (1969).

9. Krieger, I., and Woolley, P. V.. Jr.: The netabolic rate in grow th failure of prenatal onset: Comparison with growth failure of postnatal onset. Amer. J. Dis. Child., 127: 340 (1974).

10. Munro, H. N., and Fleck, A.: Recent developments in the measurement of nucleic acids in biological materials. Analyst, 9: 78 (1966).

11. Roeder, L. M1., and Stephan, J. K.: Influence of maternal diet on reprosiuctive proformance and on survival of the offspring [Abstr.]. Fed. Proc., 29:36.3 $(1970)$.

12. Watts, D. T., and Gurley, D. R.: Simple apparatus for determining basal metabolism of small animals in student laboratory. Proc. Soc. Exp. Biol. Med., 84: 585 (1953)

13. Wigglesworth, J. S.: Experimental growth retardation in the foetal rat. J. Pathol. Bacteriol., 88: 1 (1964).

14. Winick, M., and Noble, A.: Cellular response in rats during malnutrition at various ages. J. Nutr, 89: $3(1)(1966)$.

15. Zeman, F. J.: Effect on the young rat of maternal protein restriction. J. Nutr., 93: $167(1967)$.

16. Zeman, F. J.: Effect of protein deficiency during gestation on postnatal cellular development in the young rat. J. Nutr.. 100: 530 (1970).

17. Petar Preevsy, D. V. M. Was responsible for the preparation and care of the animals. His help and advice is gratefully acknowledged.

18. Dr. I. Krieger is Professor, Department of Pediatrics, Wayne State University, School of Medicine, Detroit, Michigan.

19. This research was presented at the Tenth International Congress of Nutrition, Kyoto, Japan, August 3-9, 1975

20. Requests for reprints should be addressed to: I. Krieger, M.D., Children's Hospital of Michigan, 3901 Beaubien, Detroit, Michigan 48201 (USA)

21. Received for publication March 5, 1976.

22. Accepted for publication December 2.1976.

\title{
Postnatal Triiodothyronine Concentrations in Healthy Preterm Infants and in Infants with Respiratory Distress Syndrome
}

\author{
VAL ABBASSI, (19) KULSUM MII:RCHANT, AND DAVID ABRAMSON \\ Department of Pediatrics, Georgetown University Medical C'mt'r H'ashington, D.C., USA
}

\section{Summary}

Postnatal changes in triiodothyronine $\left(T_{3}\right)$ concentration were investigated in 12 preterm infants of 26-34 weeks of gestational age. Blood for measurement of $T_{3}$ was obtained from the cord at delivery and from infants at 1 day of age and at weekly intervals for 4 weeks. Seven of the babies suffered from respiratory distress syndrome (RDS) and five were considered healthy. Gestational ages and body weight were comparable in both groups. In preterm infants with RDS, cord blood $T_{3}$ concentration was significantly lower than that in cord blood of babies without RDS ( $22 \pm 2.6$ versus $36 \pm 5 \mathrm{ng} / \mathrm{dl}, P<0.05)$. There was no significant rise in $T_{3}$ concentration of $R D S$ babies at $24 \mathrm{hr}$ of age $(22 \pm 2.6$ versus $34.0 \pm 8 \mathrm{ng} / \mathrm{dl}, P>0.05)$, and hypotriiodothyroninemia persisted for 3 weeks. At 4 weeks of age, $T_{3}$ concentration in babies with $\mathrm{RDS}$, although within the normal range $(80-190 \mathrm{ng} / \mathrm{dl})$, was significantly lower than that in the healthy preterm infants $(110 \pm 10$ versus $165 \pm 11 \mathrm{ng} / \mathrm{dl}, P$ $\leqslant 0.05)$. Postnatal $T_{3}$ changes in healthy preterm infants were characteried by the absence of the initial hypertriiodothyroninemia and by a gradual rise within the first month of life. The noted difference in the pattern of postnatal $T_{3}$ changes in healthy preterm infants compared to full term infants may reflect thyroid immaturity. The mechanism and the significance of the neonatal hypotriiodothyroninemia in RDS and its long term effects on the development of these babies remain to be investigated.

\section{Speculation}

Triiodo and tetraiodo hypothyroninemia seem to have been established as a concommitant of the respiratory distress syndrome. The significance of these findings in the pathophysiology 